\title{
SELECTION OF KOARMADA III PATROLING SHIP IN NORTH MALUKU SEA USING ANALYTIC NETWORK PROCESS METHOD
}

\author{
Supartono ${ }^{1}$, Joko Purnomo ${ }^{2}$, Bambang Ispri Bandono ${ }^{3}$, Habiby Achmad ${ }^{4}$ \\ ${ }^{1}$ Indonesia Defense University, Unhan Jakarta Indonesia \\ 2,3,4 Indonesia Naval Technology College, STTAL Surabaya Indonesia
}

\begin{abstract}
The geographical location of the North Maluku region and the extent of the sea that is difficult to reach by the security forces to cause this area prone to illegal fishing, illegal loging, illegal entry, smuggling guns and liquor. The water traffic situation in this region is also very dense, almost every time we can see the ship that passes through this line especially in ALKI III, both merchant ships, passenger vessels, and vessels Fishermen can also be encountered there. This is what led to the province of North Maluku to be very vulnerable and provide opportunities to be utilized by people and other criminal acts to commit abuses in the North Maluku waters. To maximize marine security operations in North Maluku, the TNI AL at the Koarmada operations staff need to think about and perform a mature calculation in the selection of patrol boats. This research uses the method of Analytic Network Process (ANP) because ANP is one method that can represent the level of interests of various parties by considering the interconnectedness between criteria and sub-criteria that exist. The assignment of patrol vessels has three criteria, namely tactical, technical and economic. Processing of this selection data using Super decision software for ANP calculation. The results showed that the highest priority was KRI Tatihu-853 of 0.851923 , then the second priority for KRI Albakora-857 of 0.089943, then the third priority for KRI Madidihang855 of 0.020778 , then the fourth priority for KRI Layaran-854 by 0.016319 , then fifth priority for KRI Sura-802 of 0.010707 , and the last sixth priority is KRI Kerapu-812 for 0.010329.
\end{abstract}

Keywords: Maluku Utara, Ship Selection, ANP.

\section{INTRODUCTION}

North Maluku Province is one of the islands that has 1,474 large and small islands, of which 89 islands have been inhabited while the remaining 1,385 islands are uninhabited, and has an area of \pm $145,801.10 \mathrm{~km}^{2}$ which covers a land area of $33,278.04 \mathrm{Km}^{2}$ (23.72\%) and the territorial water area of $106,977.32 \mathrm{Km}^{2}$ (76.28\%). Geographically, the northern Maluku region is in the position of

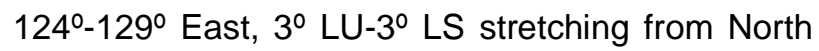
and South along $770 \mathrm{Km}$ and from West to East along $660 \mathrm{Km}$ to the north bordering the Pacific Ocean, Philipina and Palau, the south bordering the Sea Seram, in the west is bordered by the Maluku Sea which is ALKI 3, and in the east it is bordered by the Halmahera Sea and Papua.

The geographical location of the North Maluku region bordering neighboring countries such as the Philippines and Palau makes this area vulnerable to Infiltration activities from neighboring countries. The extent of the sea that is difficult to reach by security forces, making this area prone to illegal fishing activities, illegal logging, illegal entry, arms smuggling and alcohol. The situation of water traffic in this region is also very congested, almost every time we can see ships passing through this path are mainly in ALKI III, ranging from very large to small vessels, both merchant ships, passenger ships, and fishing vessels can also we meet there. This has made North Maluku province very vulnerable and provided an opportunity to be used by unscrupulous business actors and other criminal offenders to commit violations in the waters of North Maluku.

Maintaining the stability of the security of the National jurisdiction area, especially in the territorial waters of North Maluku is one of the Navy's roles which was then realized in the Sea Security Operations that had been arranged in such a way. However, in carrying out Sea Security Operations, there are still several obstacles, namely budget limitations, technical capabilities, number of ships, 
limited information, and limited supporting facilities in the North Maluku region, so that it becomes an obstacle in optimizing the implementation of Sea Security Operations. In this case the results obtained from the Marine Security Operations did not meet expectations, namely that there were still violations at sea that were not captured by the operation.

During this time in the implementation of marine security operations in the North Maluku region has not optimized the selection of the assignment of $\mathrm{KRI}$ elements in the operating sector effectively based on the technical capabilities of the ship, where there are several types of vessels of different types and capabilities, their implementation is only based on the availability of fuel and intelligence information that is not necessarily the truth. Judging from the ability of the Fleet elements and the operational costs associated with the broader sector of the sea security operations, it is felt that it is still not optimal, so that the Navy in the Koarmada Operations Staff needs to think and do a careful calculation in the assignment of Navy ships so as to secure the security operations sectors the sea. The purpose of this writing is to find a solution to the problem of choosing the assignment of elements of the KRI, in this case the Koarmada III Patrol Boat Unit in the North Maluku waters in the title of marine security operations.

In this study, researchers tried to use the Analytic Network Process (ANP) method. The ANP method is used to determine the value of alternative priority weights for identified defense equipment attributes. ANP method is able to improve the weakness of AHP in the form of the ability to accommodate the interrelationships or interdependencies between criteria or alternatives (Saaty, 2001). ANP also uses the pairwise comparison method as in AHP. Pairwise comparisons will help decision makers compare each element of the decision, because in each pairwise comparison they only concentrate on two of them (Saaty, 1993).

Based on the background of the research presented in the background, a problem statement can be formulated, namely: "How to select the Koarmada III Patrol Boat in the implementation of Marine Security Operations in the waters of North Maluku?"

To answer the problem statement above, the research question is described as follows:

a. What criteria and sub-criteria are used to formulate the decision making model in the selection of patrol unit ships in the waters of North Maluku?

b. How to formulate a decision making model for patrol unit ship selection in marine security operations in the waters of North Maluku?

The goals to be achieved in this study are as follows:

a. Determine what criteria and sub-criteria are used in formulating the decision making model of patrol unit ship selection.

b. Formulate a decision making model for the selection of patrol unit ship assignments in the waters of North Maluku.

Limitation Problems used in this Final Project research are:

a. Marine security operations are only carried out by the KRI of the Koarmada III patrol boat unit.

b. The area which is the object of research is North Maluku waters only.

C. Assignments are based on limitations or existing constraints and do not make changes to these constraints.

d. Not discussing the number of Navy patrol boat personnel.

e. The calculation of costs is only to find out the estimated operational costs, does not describe the actual situation. 


\section{MATERIAL AND METHODS}

The method used in this study is the Analytic Network Process (ANP). ANP is a method that produces a framework for overcoming the problem of decision makers without involving assumptions relating to independence between the higher level elements of the weak and the independence of the elements at one level.

ANP uses networks without having to set levels as in the hierarchy used in the AHP (Analytic Hierarchy Process), which is the starting point of ANP. The main concept in ANP is influence, while the main concept in AHP is preference. AHP with its dependency assumptions about clusters and elements is a special case of ANP. ANP is a new approach in the decision making process that provides a general framework for treating decisions without making assumptions about the independence of elements at a higher level than elements at a lower level and about the independence of the elements in a level. The advantage of ANP compared to AHP is that it frees the need to arrange components in the form of a straight chain as in a hierarchy. ANP allows the structure to develop more naturally so that it is a better way to describe what is happening in the real world. And by including dependencies, feedback and cycles of influence on the supermatrik, ANP is more objective and more likely to capture what happens in the real world.

Overall ANP is a better decision making tool than AHP, but ANP requires more work to capture facts and interactions. So for decisions that are simple and must be done quickly, more work to capture the facts and interactions makes it difficult to use.

ANP Completion Steps According to Saaty (2001):

a. Model construction and problem structuring The main objective is to identify alternatives that will be most significant in decision making. b. Paired comparison matrices that show the link

This paired comparison matrix is needed to calculate its impact on alternatives that are compared with the 9 point measurement ratio scale developed by Saaty. Performed with:

1) Determination of criteria weights is determining the criteria score obtained from the comparison value between nodes.

2) Weights are calculated with respect to one element (node) to another element (node) in the same cluster or in different clusters.

Calculation of consistency ratio. The level of inconsistency in response is called the inconsistency ratio $(\mathrm{Cl})$, the calculation of which is as follows:

$$
\mathrm{Cl}=\left(\lambda_{\max }-\mathrm{N}\right) /(\mathrm{N}-1)
$$

Where :

$\lambda_{\max }=$ The largest eigenvalue of the $\mathrm{NxN}$ is the pairwise comparison matrix $\mathrm{N} \quad=$ Number of items compared When proposing the maximum allowable inconsistent ratio is 0.1 .

c. Step 4: Establish a supermatrix and analysis The supermatrix contains a sub-matrix consisting of relationships between the two levels of the graphical model.

1) After calculating the weights between nodes and between clusters, the next step is to put the weight of each node into a supermatrix called an unweighted supermatrix.

2) After an unweighted supermatrix is obtained, the supermatrix is made to be stochastic by normalizing it with cluster weights in accordance with the concerned. 
Stochastic matrices are matrices whose number of columns is equal to one.

3) At this stage the stochastic weighted supermatrix is raised with a large rank will produce a matrix whose column values have the same values.

b. Choosing the best alternative to facilitate weight calculation using the Analytic Network Process (ANP) method using the help of Super Decisions software. Super Decisions is a special software that is designed to make it easy for users to perform ANP weighting calculations, both in modeling the relationship between clusters and between elements in a cluster, determining the value of pairwise comparison, calculating consistency ratios, calculating supermatrix, and calculating the limit matrix. The first step taken is to model the relationship between the clusters (perspective) and between the elements that exist in the cluster (objectives). Then do pairwise comparison. From the pairwise comparison, a super matrix was formed. Supermatriks obtained are supermatriks that are not weighted. Therefore, it needs to be weighted by multiplying the value in each block by the weight of the cluster which has a value of 1 (one) in each column.

The weighted supermatrix is obtained by multiplying the value of the supermatrix by the weight of the existing cluster. The weighted supermatrix formed is a stochastic matrix, where the sum of each column is one. Therefore it is necessary to find a limitting matrix to get a stable priority value. Limiting matrix search is assisted by using Super Decisions software, so that it can be easier to do calculations.

\section{RESULT AND DISCUSSION}

The following Table 1 is a breakdown of the KRI used for Fleet III Operations for Marine Security:

Table 1. List of Koarmada Patrol Ship Unit III

\begin{tabular}{|c|l|c|c|c|}
\hline No. & \multicolumn{1}{|c|}{ Nama Unsur } & Kode & Kelas & Keterangan \\
\hline 1 & KRI KERAPU-812 & KRP & FPB & Ready for operation \\
\hline 2 & KRI TATIHU-853 & TTH & PP & Ready for operation \\
\hline 3 & KRI ALBAKORA-867 & ARA & PP & Ready for operation \\
\hline 4 & KRI MADIDIHANG-855 & MDH & PP & Ready for operation \\
\hline 5 & KRI SURA-802 & SRA & FPB & Ready for operation \\
\hline 6 & KRI LAYARAN-854 & LYR & PP & Ready for operation \\
\hline
\end{tabular}

(Source: Ops Koarmada III Staff)

Analysis of data processing in research using the Analytic Network Process (ANP) method. ANP data processing is done after the ANP questionnaire results that have been distributed to experts to be filled in have been collected again. The number of experts in this ANP is six people. Making a questionnaire using the network model reference that has been formed. The questionnaire was made based on the relationship between subcriteria both innerdependence and outdependence and the relationship between preferences between criteria and goals (goal) by means of pairwise comparisons between clusters and between cluster nodes.

Data processing is performed by Superdecions software for each criterion and selecting a patrol boat.

\subsection{Determination of Patrol Ship Selection Criteria}

According to the results of a survey conducted in this study, patrol ships have several criteria that must be prioritized, including the following (Table 2: Patrol Ship Criteria): 
Table 2. Criteria for Patrol Ships

\begin{tabular}{|c|l|l|}
\hline Criteria & Sub criteria & \\
\hline \hline \multirow{4}{*}{ Technical } & Enginering & The ability of the ship's propulsion system to do the motion of the ship. \\
\cline { 2 - 3 } & Navigation & $\begin{array}{l}\text { Is an actual determination or on the map in the voyage so that it can provide } \\
\text { security assurance when the ship sails }\end{array}$ \\
\cline { 2 - 3 } Tactical & Endurance & Ability to survive the ship when the ship operates \\
\hline \multirow{5}{*}{ Economy } & weapon & $\begin{array}{l}\text { Ability and safety of ships to be equipped with equipment to attack or protect } \\
\text { against enemies. }\end{array}$ \\
\cline { 2 - 3 } & Security & $\begin{array}{l}\text { Is a condition that is comfortable or free from the possibility of danger / accident } \\
\text { that can occur. }\end{array}$ \\
\cline { 2 - 3 } & speed & $\begin{array}{l}\text { Is the ability to move in a row to cover a distance in one time interval. } \\
\text { Activities carried out intentionally and planned on the ship and its equipment in } \\
\text { order to achieve the desired conditions }\end{array}$ \\
\cline { 2 - 3 } & Care & $\begin{array}{l}\text { This criterion relates to the total costs incurred for ship operations (fuel, fresh } \\
\text { water, food, etc.) }\end{array}$ \\
\cline { 2 - 3 } & Opest & Ease of personnel in operating the ship when moving or not moving \\
\cline { 2 - 3 }
\end{tabular}

\subsection{Making Model Construction}

Clusters are made based on the evaluation criteria used, namely Technical Groups, Tactical Groups and Economic Groups. While the Alternative Groups for patrol boat selection were selected in this study; namely: (1) KRI Grouper-812; (2) KRI Tatihu-853; (3) KRI Albakora-857; (4) KRI Madidihang-855; (5) KRI Sura-802; and (6) KRI Layaran-854.
Next determine the interdependence relationships between criteria in one group (Inner dependency) or between groups (outer dependency). The determination of the interdependent relationship is based on a questionnaire. And the results of the tabulation of the answers of 6 experts who have calculated the geomean value, can be seen in Table 3 as follows:

Table 3. Tabulation of Geomean Values from 6 Experts

\begin{tabular}{|l|l|l|l|}
\hline Kriteria & TEKNIS & Taktis & Ekonomi \\
\hline Teknis & 1.000 & 0.179 & 5.000 \\
\hline Taktis & 5.593 & 1.000 & 5.288 \\
\hline Ekonomi & 0.200 & 0.189 & 1.000 \\
\hline Total & $\mathbf{6 . 7 9 3}$ & $\mathbf{1 . 3 6 8}$ & $\mathbf{1 1 . 2 8 8}$ \\
\hline
\end{tabular}

\begin{tabular}{|c|c|c|c|c|c|c|c|}
\hline ALTERNATIF & TEKNIS & & & & & & \\
\hline & PERMESINAN & KRI Kerapu - 812 & KRI Tatihu - 853 & KRI Albakora - 857 & KRI Madidihang - 855 & KRI Sura - 8Q2 & KRI Layaran - 854 \\
\hline & KRI Kerapu - 812 & 50 & 1000 & 1.000 & 1.000 & 1000 & 1.000 \\
\hline & KRd Tatihu -853 & 1000 & 100 & 5.000 & 5.000 & 0.333 & 3,000 \\
\hline & KRi Albakora - 857 & 1.000 & 0.200 & $8 \times 0$ & 5.000 & 5000 & 5000 \\
\hline & KRI Madidihang - 855 & 1.000 & 0200 & 0.200 & 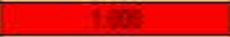 & 2000 & 2000 \\
\hline & KRI Sura - 802 & 1000 & 3000 & 0.200 & 0.500 & 1620 & 5000 \\
\hline & KRJ Layaran - 854 & 1.000 & 1.333 & 7000 & 0.500 & 0.200 & 100 \\
\hline & & & & & & & \\
\hline & NAVIGASI & KRI Kerapu - 812 & KRI Tatihu - 853 & KRI Albakora - 857 & KRI Madidihang - 855 & KRI Sura - 802 & KRI Layaran - 854 \\
\hline & KRJ Kerapu -812 & 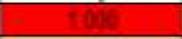 & 1.000 & 1.000 & 1.000 & 1000 & 1.000 \\
\hline & KRa Tatihu -853 & 1.000 & 200 & 5.000 & 5.000 & 0333 & 3000 \\
\hline & KRJ Albakora - 857 & 1.000 & 0200 & 50 & 5.000 & 5000 & 5,000 \\
\hline & KRI Madidihang - 855 & 1000 & 0200 & 0200 & 180 & 2000 & 2000 \\
\hline & KRd Sura - 802 & 1000 & 3.000 & 0.200 & 0.500 & 46 & 5.000 \\
\hline & KRd Layaran - 854 & 1000 & 0333 & 7.000 & 0,500 & 0.200 & 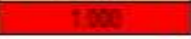 \\
\hline & & & & & & & \\
\hline & ENDURANCE & KRI Kerapu - 812 & KRI Tatihu - 853 & KRI Albakora - 857 & KRJ Madidihang - 855 & KRI Sura - 802 & KRI Layaran - 854 \\
\hline & KRI Kerapu - 812 & 1060 & 1000 & 1.000 & 1.000 & 3000 & 3000 \\
\hline & KRs Tatihu - 853 & 1.000 & 80 & 5.000 & 5.000 & 0.500 & 3000 \\
\hline & KRi Albakora - 857 & 1000 & 0.200 & 190 & 5.000 & 5000 & 5000 \\
\hline & KRI Madidihang - 855 & 1000 & 8200 & 0200 & 100 & 2000 & 2000 \\
\hline & KRi Sura - 802 & 0333 & 2000 & 0.200 & 0,500 & 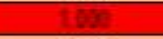 & 5.600 \\
\hline & KRJ Layaran - 854 & 0.333 & 0.333 & 7000 & 0.500 & 0200 & 18 \\
\hline
\end{tabular}


TAKTIS

\begin{tabular}{|l|c|c|c|c|c|c|}
\hline \multicolumn{1}{|c|}{ PERSENJATAAN } & KRI Kerapu - 812 & KRI Tatihu - 853 & KRI Albakora - 857 & KRI Madidihang - 855 & KRI Sura - 802 & KRI Layaran - 854 \\
\hline KRI Kerapu - 812 & 1.000 & 3.000 & 3.000 & 3.000 & 3.000 & 3.000 \\
\hline KRI Tatihu - 853 & 0.333 & 1.000 & 5.000 & 5.000 & 1.000 \\
\hline KRI Albakora - 857 & 0.333 & 0.200 & 1.000 & 5.000 & 5.000 & 3.000 \\
\hline KRI Madidihang - 855 & 0.333 & 0.200 & 0.200 & 1.000 & 2.000 & 5.000 \\
\hline KRI Sura - 802 & 0.333 & 1.000 & 0.200 & 0.500 & 2.000 \\
\hline KRI Layaran -854 & 0.333 & 0.333 & 7.000 & 0.500 & 0.200 & \\
\hline
\end{tabular}

\begin{tabular}{|c|c|c|c|c|c|c|}
\hline KEAMANAN & \begin{tabular}{|l|} 
KRI Kerapu - 812 \\
\end{tabular} & \begin{tabular}{|l|} 
KRI Tatihu - 853 \\
\end{tabular} & KRI Albakora - 857 & KRI Madidihang - 855 & KRI Sura - 802 & KRI Layaran - 854 \\
\hline KRI Kerapu - 812 & 1.000 & 3.000 & 3.000 & 3.000 & 3.000 & 3.000 \\
\hline KRI Tatihu - 853 & 0.333 & 1.000 & 5.000 & 5.000 & 1.000 & 3.000 \\
\hline KRI Albakora - 857 & 0.333 & 0.200 & 1.000 & 5.000 & 5.000 & 5.000 \\
\hline KRI Madidihang - 855 & 0.333 & 0.200 & 0.200 & 1.000 & 2.000 & 2.000 \\
\hline KRI Sura - 802 & 0.333 & 1.000 & 0.200 & 0.500 & 1.000 & 5.000 \\
\hline KRI Layaran - 854 & 0.333 & 0.333 & 7.000 & 0.500 & 0.200 & 1.000 \\
\hline
\end{tabular}

\begin{tabular}{|l|c|c|c|c|c|c|}
\hline \multicolumn{1}{|c|}{ KECEPATAN } & KRI Kerapu - 812 & KRI Tatihu - 853 & KRI Albakora - 857 & KRI Madidihang - 855 & KRI Sura - 802 & KRI Layaran - 854 \\
\hline KRI Kerapu - 812 & 1.000 & 3.000 & 3.000 & 3.000 & 3.000 & 3.000 \\
\hline KRI Tatihu - 853 & 0.333 & 1.000 & 5.000 & 5.000 & 0.143 \\
\hline KRI Albakora -857 & 0.333 & 0.200 & 1.000 & 5.000 & 5.000 & 3.000 \\
\hline KRI Madidihang - 855 & 0.333 & 0.200 & 0.200 & 1.000 & 2.000 & 2.000 \\
\hline KRI Sura - 802 & 0.333 & 7.000 & 0.200 & 0.500 & 1.000 & 2.000 \\
\hline KRI Layaran - 854 & 0.333 & 0.333 & 7.000 & 0.500 & 0.200 \\
\hline
\end{tabular}

\begin{tabular}{|c|c|c|c|c|c|c|}
\hline EKONOMI & & & & & & \\
\hline PERAWATAN & KRI Kerapu - 812 & \begin{tabular}{|l|} 
KRI Tatihu - 853 \\
\end{tabular} & KRI Albakora - 857 & KRI Madidihang - 855 & KRI Sura - 802 & KRI Layaran - 854 \\
\hline KRI Kerapu - 812 & 1.000 & 3.000 & 3.000 & 3.000 & 3.000 & 1.000 \\
\hline KRI Tatihu - 853 & 0.333 & 1.000 & 5.000 & 5.000 & 0.333 & 3.000 \\
\hline KRI Albakora - 857 & 0.333 & 0.200 & 1.000 & 5.000 & 5.000 & 5.000 \\
\hline KRI Madidihang - 855 & 0.333 & 0.200 & 0.200 & 1.000 & 2.000 & 2.000 \\
\hline KRI Sura - 802 & 0.333 & 3.000 & 0.200 & 0.500 & 1.000 & 5.000 \\
\hline KRI Layaran - 854 & 1.000 & 0.333 & 5.000 & 0.500 & 0.200 & 1.000 \\
\hline
\end{tabular}

\begin{tabular}{|l|c|c|c|c|c|c|}
\hline \multicolumn{1}{|c|}{ BIAYA } & KRI Kerapu - 812 & KRI Tatihu - 853 & KRI Albakora - 857 & KRI Madidihang - 855 & KRI Sura - 802 & KRI Layaran - 854 \\
\hline KRI Kerapu - 812 & 1.000 & 3.000 & 3.000 & 3.000 & 3.000 \\
\hline KRI Tatihu - 853 & 0.333 & 1.000 & 3.000 & 3.000 & 0.333 \\
\hline KRI Albakora -857 & 0.333 & 0.333 & 1.000 & 5.000 & 3.000 \\
\hline KRI Madidihang -855 & 0.333 & 0.333 & 0.200 & 1.000 & 2.000 \\
\hline KRI Sura - 802 & 0.333 & 3.000 & 0.200 & 0.500 & 2.000 \\
\hline KRI Layaran -854 & 0.333 & 0.333 & 3.000 & 0.500 & 1.000 & 0.200 \\
\hline
\end{tabular}

\begin{tabular}{|l|c|c|c|c|c|c|}
\hline \multicolumn{1}{|c|}{ OPERASIONAL } & KRI Kerapu - 812 & KRI Tatihu - 853 & KRI Albakora - 857 & KRI Madidihang - 855 & KRI Sura - 802 & KRI Layaran - 854 \\
\hline KRI Kerapu - 812 & 1.000 & 7.000 & 3.000 & 3.000 & 5.000 \\
\hline KRI Tatihu - 853 & 0.143 & 1.000 & 3.000 & 3.000 & 0.333 \\
\hline KRI Albakora - 857 & 0.333 & 0.333 & 1.000 & 5.000 & 3.000 \\
\hline KRI Madidihang - 855 & 0.333 & 0.333 & 0.200 & 1.000 & 3.000 \\
\hline KRI Sura - 802 & 0.200 & 3.000 & 0.200 & 0.296 & 3.000 \\
\hline KRI Layaran - 854 & 0.333 & 0.333 & 7.000 & 0.296 & 1.000 & 0.200 \\
\hline
\end{tabular}

Based on Table 3, it can be seen the results of the tabulation of criteria, sub criteria and alternatives, it is said there is a relationship between $\mathrm{Vi}$ and $\mathrm{Vj}$ if the cell value is more than 1 , for example in the Criteria Matrix Table between technical (Vi) and economics ( $\mathrm{Vj}$ ) has a value equal to 5 , then it can be said between technical and economics have a relationship or dependence.

Based on Table 3, it can be seen the results of the tabulation of criteria, sub criteria and alternatives, it is said there is a relationship between $\mathrm{Vi}$ and $\mathrm{V}$ if the cell value is more than 1 , for example in the Criteria Matrix Table between technical $(\mathrm{Vi})$ and economics $(\mathrm{Vj})$ has a value equal to 5 , then it can be said between technical and economics have a relationship or dependence.

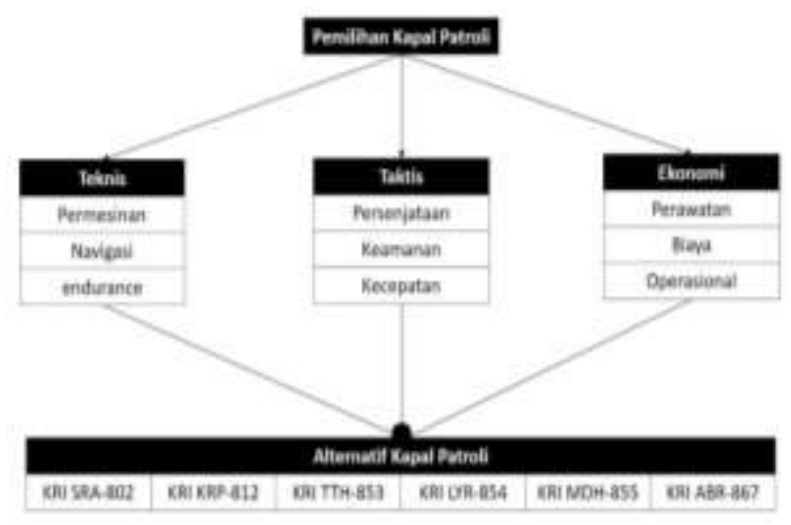

Fig.1 Hierarki ANP Model 


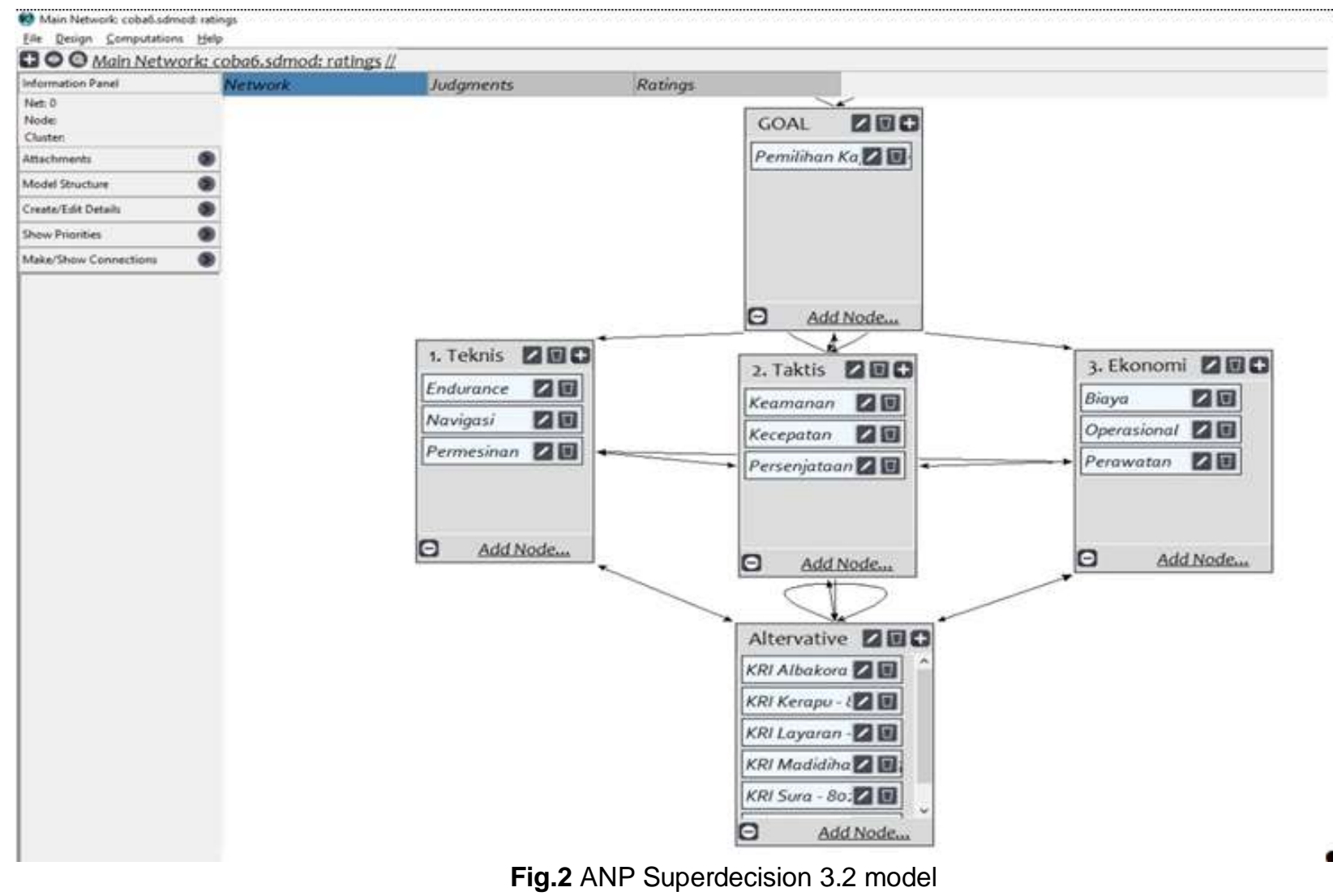

\subsection{Results of Paired / Group Comparative Matrices Matrices}

Pairwise comparison matrices between groups are made based on expert assessments, regarding patrol boat selection based on criteria and sub-criteria. The next step is looking for an assessment of the average value of the assessment of the 6 expert answers. This is necessary because there is one value that can be entered into the model. The average used is the geometric mean, more clearly see Table 3 . The results of the paired comparison matrix of the data after being entered into the ANP model in superdecision software, can be seen in Figure 1, as follows:

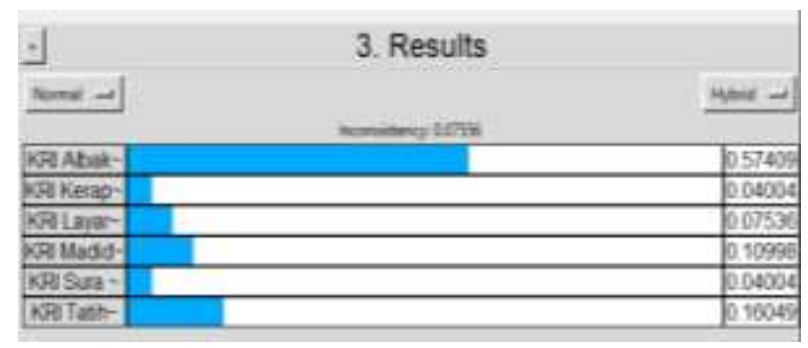

Fig.3 Results of Pairwise Comparison between Criteria with the help of Superdecision Software for Patrol Ship Selection

Based on Figure 3, it can be seen the sequence of selection of operational vessels in the pairwise comparison based on priority value (eigen vector), where KRI Albakora-857 ranks first with a value of 0.57409 , then followed by second rank by KRI Tatihu-853 with a value of 0.16049 , then ranks the third was followed by KRI Madidihang-855 with a value of 0.10998 , then the fourth was followed by the KRI Layaran-854 with a value of 0.07536 , then the fifth and sixth were followed by KRI Kerapu-812 and KRI Sura-802 with a value of 0.4004 . Besides that, the consistency index $(\mathrm{Cl})$ value is also known, the assessment is said to be consistent, if the CR value is $<0.1$. $C R$ value of 0.07556 in the pairwise comparison model, so it can be concluded that the six experts have been consistent in assessing the pairwise comparison.

After a pairwise comparison between criteria is made, the next step is to create a group matrix (Cluster Matrix). The group matrix for this model can be seen in Table 4. as follows: 
Table 4. Group Matrix for Patrol Vessel Selection

\begin{tabular}{|c|c|c|c|c|c|}
\hline Custers & 1Tehis & 2Titis & 3. Bronom & Aterafure & 602 \\
\hline LTáris & arrocos: & $025 \times 0$ & Q333333 & afforl: & 020008 \\
\hline 2 Tads & Drtage & $05 \mathrm{wm}$ & 0333333 & 02085 & 12000 \\
\hline 3. Fhoromi & entast & 12560 & cowero & 0.007) & $02000 \%$ \\
\hline Aterafive & ange? & 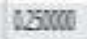 & 0333333 & 0400005 & $1200 \times$ \\
\hline GOH & arrocosos & nowoto & ocwor & 0.00035 & $0200 \times 2$ \\
\hline
\end{tabular}

\subsection{Manufacture of Supermatriks}

Supermatrix consists of 3 types, namely: (1)

Unweighted Supermatrix; (2) Weighted

Supermatrix; and (3) Limit Super-matrix.

Supermatriks are made based on data on the results of pairwise comparisons between groups / criteria / alternatives. In supermatriks, how to read the table is the criteria in the left column affect the criteria in the left column affect the criteria in the top row.

An unweighted supermatrix is made based on pairwise comparisons between groups / criteria / alternatives, by entering a priority value (eigen vector) into the matrix that corresponds to the cell. The unweighted supermatrix can be seen in Table 5 as follows:

Table 5. UnweightedSupermatrix

\begin{tabular}{|c|c|c|c|c|c|c|c|c|c|c|c|c|c|c|c|c|}
\hline Ouster: & Grosinat: & Naiges & Pereinn & Cemann & Kesepten & Pessegitan & Bay & Operiond & Preaston & Q Q Hotann-027 & 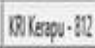 & 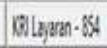 & 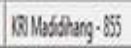 & Gisun:Q1 & 197th. -85 & Penthen lepilopara \\
\hline \multirow[t]{3}{*}{ 1.Tents } & comolo & 100000 & 00000 & 0233333 & 033333 & 0333333 & 0.333333 & 0.333833 & 033333 & andis & 02631 & 011124 & 0157008 & arison & 0157288 & 0233333 \\
\hline & 니이 & acomoun & 000000 & 0333333 & Q333333 & 033333 & 0333333 & 033333 & 0333333 & Q113233 & 0157068 & a1720 & 024311 & 033:14 & 0243911 & 033333 \\
\hline & corren & aroun & conoun & 033333 & 033333 & 033333 & 033333 & $033 \times 3$ & $033 \times 3$ & 081213 & 06952 & $07 \times 85$ & 059824 & Q263X & 093844 & 03333 \\
\hline \multirow[t]{3}{*}{ 2Tides } & 013333 & $033 \times 33$ & 033333 & conouno & aroum & 033333 & 033333 & 033:33 & 033333 & Q14:15 & 026511 & 01720 & 024311 & 031:14 & 015068 & 033333 \\
\hline & 103333 & 1033:3 & 0.33333 & atouno & 000000 & 0333333 & 0.33333 & 03333 & 0.33333 & okes: & 015065 & 01124 & 0.5005 & ars 350 & Q243311 & $033 \times 33$ \\
\hline & 123:3 & cos33:3 & 033333 & osemou & andon & 033333 & 0333333 & 03383:3 & 03333 & 0755i: & 05s 804 & arzash & CSSSSA & QAS3XX & 053534 & $033 \times 33$ \\
\hline \multirow[t]{3}{*}{ 3. Boromi } & 13333:3 & 033333 & 0.33333 & 033333 & 033333 & 033333 & aroun & aroun & 000000 & 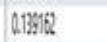 & 031014 & Q1535y & 02437 & alszex & Q24 2911 & 03333 \\
\hline & 023333 & 033333 & 0.33333 & 0233333 & 0333333 & 0333333 & 0 anom & asoulo & a 10000 & 008367 & alswo & Cox:81 & CoxOH & 033:24 & Q15568 & 033333 \\
\hline & 103333 & $03 \times 33$ & 0.333333 & 033331 & 033333 & 033333 & 000000 & conoun & 0.0000 & atmin & $\cos 20$ & at3 65 & $058 \times 17$ & Q.53X & 053524 & 033333 \\
\hline \multirow[t]{6}{*}{ Alendie } & QS595: & 0.606 & 058228 & QA7\%24 & QFs & Q & 05:08? & QReats & 0.5is4 & andono & aroun & 00000 & 0000000 & 000000 & Q156567 & $057 \%$ \\
\hline & Maros & ANESE & QDegry & ans506 & QWKE: & 0.533:" & Won:S & $0.651 \pm$ & 0,0587 & 000000 & a10s: & conous & 000000 & andon & artex: & QDNoOS \\
\hline & 000007 & aा126 & argis & Q1DEX & Q135671 & 0.5201 & a1852 & 006020 & Q15419 & acouno & 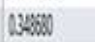 & anoulo & conoun & 000000 & Q165eC? & 007383 \\
\hline & 022012 & 021588 & 0.4572? & $012 \div 151$ & Q13N2 & 02424 & Q11008 & 016024 & Q14833 & 0 & 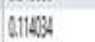 & conoum & conoum & $0 \times 0 \times 0$ & arken? & alkeg? \\
\hline & WWIS & ASKXX & aceses & ussuos & Q4S580 & 0.62515 & OLSES & 0101116 & COSB & andour & 02848 & onoulu & 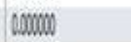 & 남ov & 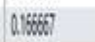 & andes \\
\hline & Q & areses: & ansivis! & $010 \%$ & 0002567 & a13:30 & $0 \times 2 \times 3$ & 0128066 & Q47000 & 000000 & 010863 & conoun & onomon & a conou & arem & 010065 \\
\hline 604. & ando & andion & aroum & 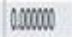 & 000000 & anowio & aroum & areoulo & aremol & onem & $100 \mathrm{~mol}$ & aroul & ㄴown & anowoll & טsom & $100 \mathrm{~mol}$ \\
\hline
\end{tabular}

\subsection{Weighted supermatrix}

The weighted supermatrix obtained by means of the values in the group matrix used to give weighted supermatrix weighting. The way to give weight is to multiply the value in the group matrix cell with the value in each cell of the appropriate unweighted matrix. The weighted supermatrix can be seen in Table 6 as follows:

Table 6. Weighted Supermatriks

\begin{tabular}{|c|c|c|c|c|c|c|c|c|c|c|c|c|c|c|c|c|}
\hline Oastes & indonnet & Naigers & Pemenn & Kensten & Keseptun & Presejtam & Baga & Cosessons & Peanzan & 19.Ababan-857 & Makerov-81? & 10 lagm- 84 & 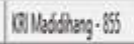 & DSSen-818 & OTtebs-63 & Penilizn lapl (Opeses \\
\hline \multirow[t]{3}{*}{ 1.Tens } & orean: & conouno & ontorou & Q1111111 & AIIIIIII & 000333 & 0.111111 & Q111111! & Alitilil & 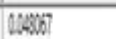 & a16sil & 00028 & Q101013 & 0131\%? & ansty & anted? \\
\hline & oromolo & conoulo & ondoul & Q1111111 & Q QIIIIII & 000333 & Qt111III & allitit & Q111111 & anse & 015:5 & Q1195? & Quevess & 020002 & Q astox & ansed? \\
\hline & ossono: & conouro & 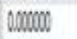 & Qt11111 & attiliti & 008333 & Q1t11tit & attitit & Al11111 & DSWDS & CMSW & 0.652 & OSYTX & O3X01 & Q239\% & anWW \\
\hline \multirow[t]{3}{*}{ 2Tils } & 1235316 & 023916 & 02995 & cosouno & 0000000 & 003333 & QtIItII & Q.111111 & Q111111 & Ocsalus & 00641 & OQB3:S & OOOWE & 00Titis & 002810 & cosedet \\
\hline & 023916 & 023916 & 0298 & a $0000 \mathrm{OO}$ & opono & OOx333 & Q1111111 & Q at11111 & L111111 & OATs: & cossin & OQDTS & CONSI: & DOAT28 & OWOES & avese? \\
\hline & 023916 & 023916 & 023:5 & a carono & anomor & 000333 & QfIIIIII & Q1111111 & atiliti & ANW & Q140X & 0.17\%क & $0400 ?$ & Q11921 & 01485 & 006605 \\
\hline \multirow[t]{3}{*}{3 Eoroni } & Cosses:8 & CODSA14 & 003718 & Q1111111 & Q Q1111111 & 003333 & conomol & 다잉 & 000000 & (coses & (101355 & Qubos: & ONE13: & 0001720 & 02196 & ansedent \\
\hline & OSOM & OQSA18 & ONATIX & QtIIIII & QtIIIIII & 000333 & onoun & cronol & anoun & OLTTIO & (1972) & 0007:2 & Q00735 & Q01235 & Qutsil: & 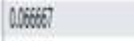 \\
\hline & Oasorye & 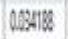 & OQXIX & Q1111111 & Q altiti1 & 003333 & oporoun & coroun & 100000 & ONOWI & Q 043395 & OAxE5 & ONSWX3 & OANBSA & aseare & cosk6e? \\
\hline \multirow[t]{6}{*}{ Atendit: } & cosise & OQDTR & 01000 & 01504 & 0.5654 & DIILK & 016783 & 016223 & 01521 & acoum & ancoul & aromo: & a caroulo & a carcoul & acoum & 0.1157 \\
\hline & $000 \% 5 \%$ & consos & 001618 & 0ors35 & 0015:8 & and & 00758 & wot73is & ADis8 & aromo & anoul & a comoul & convolo & ancouro: & anom & anorous \\
\hline & octsis & 012017 & 003936 & OCSA6 & COSE24 & Neexo & Q0B557 & CONDS & OLESA3 & crowaro & conoce: & onomolo & anomo & ancous & 대음 & 001573 \\
\hline & 003936 & cosses & 00073: & aum? & owert? & QCSSBO & ONFHA & CBSLEX & 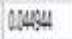 & 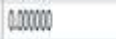 & conotit & Conouno & corouno & a 000000 & oranor & 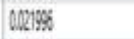 \\
\hline & 000724 & CaOSis! & 001147 & Quteses & 001558 & aress & 01012131 & Cos3 & QDisos & crovolo & conoul & orouno & Q & ancour & oromor & conoves \\
\hline & 002891 & an: 16 & OOMGIS & aress & QUE2 & ossene & acesest & WNes & 0.2333 & aroun & anoul & arowo & a comolo & ancoul & asom & ODXXOS \\
\hline 601 & oramour & conerou & oneroulo & arano & comour & a onomo & cacouio & 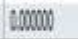 & (1000000 & C100000 & torous & ancouro & 0000000 & ancouro & cancous & 02000 \\
\hline
\end{tabular}




\subsection{Supermatrix limit}

Limit supermatrixes are obtained by increasing the weighted supermatrix to its limit by multiplying itself. When the priority values in each column are the same, a limit matrix is obtained. The limit super matrix can be seen in Table 7 , as follows:

Table 7. Supermatriks Limit

\begin{tabular}{|c|c|c|c|c|c|c|c|c|c|c|c|c|c|c|c|c|}
\hline Cluters & Enorance & Nanigas & Pemeinan & Keamens & Kecepten & Pessejitan & Bioga & Opersicesl & Preantan & KI Abscen-857 & KRN Kerop - 812 & KN Lagren-854 & KR Medishang - 855 & 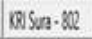 & KQ Tethu- -858 & Periliten Kaps Opersi \\
\hline \multirow[t]{3}{*}{ 1. Tobis } & $0.67 \%$ & 0,66740 & 096720 & 0.66740 & 006720 & $0.067 / 20$ & 0.66740 & 0.66720 & 0.067240 & Co6784 & $0.67 \% 4$ & 006704 & 0067240 & 006824 & 0.66724 & 0.06724 \\
\hline & 0075343 & 0075343 & $00753 B$ & 0075343 & 007530 & $0075 \times 3$ & 0075343 & 0075513 & $0075 \times 13$ & $00753 \times 3$ & 0.07553 & 0075363 & 007513 & $00755 \times 13$ & $0075 \times 3$ & $0075 \times 13$ \\
\hline & 015626 & 0,156626 & 015626 & 0.15026 & 0156626 & Q15626 & 0.156626 & 0.15626 & 0.15626 & 0.15626 & 0.15626 & 0.15626 & 015626 & 0.13626 & 015626 & 0.15626 \\
\hline \multirow[t]{3}{*}{ 2Tads: } & andono & Q10060 & 0.10060 & 0.10070 & 0.10680 & 010060 & Q100600 & 0.10080 & 0.1060 & 0.10860 & 010580 & 0.100600 & 0.10080 & Q14060 & 010660 & 0.10680 \\
\hline & $01: 453$ & 01045? & Q110453 & Q10453 & Q10u453 & 0.10453 & 0.10458 & 0.10453 & 0.1453 & Q61453 & 010453 & 0.10453 & 0.10453 & 011453 & 0.10453 & 0.10453 \\
\hline & Q13369 & Q113609 & Q133609 & Q.13369 & 013369 & 013360 & 0.13838 & Q 13350 & 0.13360 & Q.13309 & 0133609 & 0.13569 & 0.13569 & 013369 & Q.133609 & 0.133609 \\
\hline \multirow[t]{3}{*}{ 3. Elotonni } & OOA162. & OABSE & Dacisi: & ONQW102 & angiti2 & Q045162 & OAQ162 & Q0QS162 & 0.448182 & OASE1E2 & Q003152 & Oans162 & ans 162 & 0.048162 & Co45162 & 0.048162 \\
\hline & Co46281 & 004621 & OOS621 & O04621 & acesel & adeseri & OMEO21 & COSEOL1 & OA4tel & OAKSEL1 & ack6281 & OQAESEI & OaESE21 & OQA46281 & OQA6821 & OA45281 \\
\hline & Oons:5s) & Cos5350 & QCS55550 & 0.657550 & 0057350 & 0.06750 & 0.55750 & 0,057550 & 0057550 & 0.057530 & 007350 & 0.07750 & 0.157530 & O057530 & 0.07750 & 0007550 \\
\hline \multirow[t]{6}{*}{ Alendie } & Q101319: & Q.1013:9 & 0.101319 & Q.101319 & 0101319 & 0.10319 & 0.101319 & 0.101319 & 0.101319 & AxN13: & 0101319 & 0.101319 & 0101319 & 0.101319 & 0.10139 & 0.101319 \\
\hline & ont129: & 0.01129 & a01129 & 005128 & antixs & adrieg & 0001129 & 001129 & 0001129 & 001129 & ablites & obrixg & aoles & ODIISO & ODN1129 & 001129 \\
\hline & 0025017 & 0000017 & 008017 & 0002017 & anses:17 & 0028017 & 0008017 & 0000017 & Q0820017 & O0.8007 & 003017 & 0020017 & 0008017 & O028017 & 00280017 & 0002017 \\
\hline & 0.030597 & Cos3357 & 0050357 & 0000357 & Q000357 & 0023557 & 0000357 & 0003357 & 0030357 & C03035? & 0033557 & 003359 & 0.033357 & 0030357 & 0030527 & 0033537 \\
\hline & 001156 & 041156 & $00115 \%$ & 0011566 & Dotis: & 00015156 & $0011 \% 6$ & $0015 \% 6$ & 0.01156 & Col15\% & Q001156 & 0011568 & 0011560 & 0011566 & 0011566 & 00015060 \\
\hline & 000227 & aover & anveI & anvel? & DOEQ2T & ONove? & Q0,2027 & aneer? & ONQ227 & OORED & 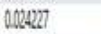 & 000227 & oneve? & ONOE2T & 0.02027 & 0020227 \\
\hline 601. & comoun & ancono & acrouno & a couvolo & Q 100000 & ac00000 & a conoun & acouno & opown: & conoun & acouno & ac000000 & acouno & 0000000 & osponou & oconoulo \\
\hline
\end{tabular}

\subsection{Final Priority}

The final priority values are obtained from the limit matrix in Figure 4. Next, normalization is done based on groups, so that the total priority values in each group are one. So the last priority value can be seen in Table 8, as follows:

Fig.4 Final Priority Values for Selecting Patrol Vessels

\begin{tabular}{|c|c|c|c|}
\hline \multicolumn{4}{|c|}{ Here are the priorities. } \\
\hline Icon & Name & $\sqrt{\text { Normalized by Cluster }}$ & $\sqrt{\text { Limiting }}$ \\
\hline No Icon & KRI Albakora - 857 & 0.08995 & 0.008858 \\
\hline No Icon & KRI Kerapu - 812 & 0.01033 & 0.001017 \\
\hline No Icon & KRI Layaran - 854 & 0.01632 & 0.001607 \\
\hline No Icon & KRI Madidihang - 855 & 0.02078 & 0.002046 \\
\hline Nolcon & KRI Sura - 802 & 0.01070 & 0.001054 \\
\hline No kon & KRI Tatihu - 853 & 0.85193 & 0.083900 \\
\hline No icon & Biaya & 0.30550 & 0.174811 \\
\hline No kon & Operasional & 0.28568 & 0.163472 \\
\hline No kon & Perawatan & 0.40883 & 0.233939 \\
\hline No icon & Pemilihan Kapal Patroli & 1.00000 & 0.039922 \\
\hline No icon & Ekonomi & 0.00000 & $\longdiv { 0 . 0 0 0 0 0 0 }$ \\
\hline Nolcon & Taktis & 0.00000 & 0.000000 \\
\hline No lcon & Teknis & 1.00000 & 0.000010 \\
\hline No Icon & Keamanan & 0.27235 & $\longdiv { 0 . 0 3 9 4 0 2 }$ \\
\hline No icon & Kecepatan & 0.25218 & 0.036484 \\
\hline No kcon & Persenjataan & 0.47548 & 0.068790 \\
\hline No Icon & Endurance & 0.25420 & 0.036779 \\
\hline Nolcon & Navigasi & 0.28845 & 0.041735 \\
\hline No kon & Permesinan & 0.45735 & 0.066173 \\
\hline
\end{tabular}

\subsection{Determination of Priority for Selection of} Operational Vessels

The priority values for the selection of operational vessels are obtained after normalization, can be seen in the Table and Figure as follows: 


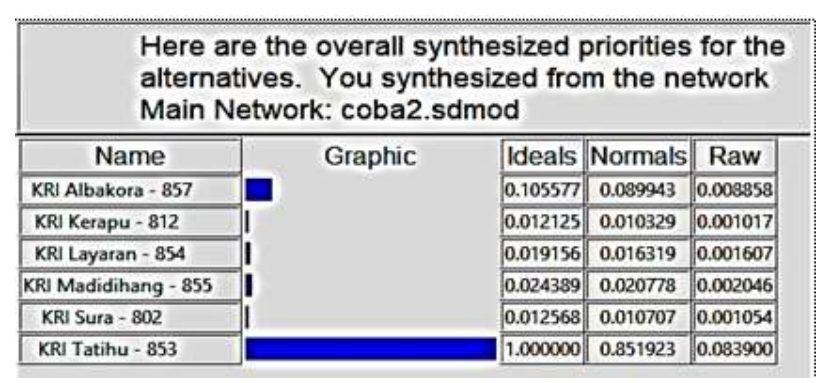

Fig.5 Ranking of Patrol Boat Selection

Based on figure 5 from the normalization results, the first priority value for $\mathrm{KRI}$ Tatihu- 853 is 0.851923, then the second priority for KRI Albakora-857 is 0.089943 , then the third priority for KRI Madidihang-855 is 0.020778 , then the fourth priority is for KRI Layaran-854 by 0.089943 0.016319 , then the fifth priority for KRI Sura-802 is 0.010707 , and the sixth last priority is KRI Kerapu812 with 0.010329 .

\section{CONCLUSION}

Based on the results of research on ANP analysis for selecting the best ships for the assignment of elements of the Koarmada Patrol Boat III in the implementation of marine security operations in the waters of North Maluku, it can be concluded:

a. Criteria (Technical, Tactical, and Economic), and technical sub criteria (Machinery, Navigation and Endurance), tactical (Armament, Safety, and Speed) and economics (Maintenance, Costs, and Operations) that have had expert assessments in the category consistent with the value of $\mathrm{Cl}<0.1$ is equal to 0.0755 in the pairwise comparison model. The criteria and sub-criterion variables are used in the selection of the best $\mathrm{KRI}$ for the assignment of the Patrol Koarmada III unit elements in the implementation of marine security operations in the waters of North Maluku.

b. The formulation of the decision making model uses the ANP method with the help of super decision software for matrix calculation so that it produces the best weight value. c. The result of ANP calculation after normalization is the first priority value for $\mathrm{KRI}$ Tatihu-853 is 0.851923 , then the second priority for KRI Albakora- 857 is 0.089943 , then the third priority for KRI Madidihang-855 is 0.020778 , then the fourth priority is for KRI L Cruise-854 by 0.089943 , then the third priority is for $\mathrm{KRI}$ Madidihang- 855 by 0.020778 , then the fourth priority is for $\mathrm{KRI} \mathrm{L}$ Cruise- 854 by 0.089943 . 0.016319 , then the fifth priority for KRI Sura-802 is 0.010707 , and the sixth last priority is KRI Kerapu-812 with 0.010329 .

\section{FUTURE WORK}

The suggestions that can be put forward in this study are as follows:

a. For the Navy

1) It is hoped that the results of this study will be taken into consideration in the decision making of the Indonesian Navy, especially the Operations Staff of the Third Army of the Army and the Sea Safety Group III (Guskamla III) as well as the commander of the KRI element (Patrol Boat) in determining the strategy of implementing sea security operations.

2) It is hoped that the KRI Tatihu-853 Ship can optimize marine security operations carried out by KRI elements (Patrol Vessels) located in the waters of North Maluku.

3) It is hoped that the KRT Tatihu-853 Ship can be applied in the Operations Staff of Koarmada III and Guskamla III in the context of assigning Navy patrol ships to the operations sector.

b. Share further research

1) It is expected that the results of this study can provide information in the selection of operational vessels for the assignment of the Koarmada III Patrol Ship unit in carrying out sea security operations in the waters of North Maluku. 
2) It is hoped that the results of this study can provide information related to the criteria and sub-criteria matrices in assisting in the decision making process for the best KRI selection.

\section{REFERENCES}

A, Hamdan, 2003. Operation Research, An Introduction toventh Edition. Prentice Hall, New Jersey USA.

A, Hamzah, (1984). Indonesian territorial sea and waters. Akademia Pressindo, Jakarta.

Agus T. 2011. Selection of Aks Helicopters as Target Reporting Unit Helicopters in Amy Class Class Post-Yakhont Missile Installation Using ANP Method. Faculty of Industrial Management Engineering STTAL Suarabaya.

Asops Kasal, 2005. The Navy Operational Concept in the context of Upholding Sovereignty and Security at Sea, FPSO, Jakarta.

Aswir and Pasaribu, 2017. Supplier Selection Using the Analytic Network Process Method at PT. UTPE. Unpres Jakarta Industrial Engineering Faculty.

Asops Kasal, 2004. Sea Safety Operations Manual.

Daskin, 2008 What You Should Know About Location Modeling

Firmanto, H, 2006. Operations Research, Solver: Marine Transportation lecture module, ITS Marine Technology Faculty, Surabaya.
Indonesian Navy Headquarters. 2009, PERKASAL / 39 / V / 2009 TNI AL Basic Policy Towards Minimum Essential Force, Jakarta.

Najib, 2014. Election of Airborne Deterrent Combat Weapons for Makassar KRI Class LPD Ships with Fuzzy MCDM Approach. Faculty of Industrial Management Engineering STTAL, Surabaya.

Promentilla, MAB, Tapia, JFD, Arcilla, JFD, Dugos, NP, Gaspillo, D., Roces, SA, and Tan, RR, 2013. Interdependent tranking of sources and sinks in CCS systems using the analytic network process, Environmental Modeling \& Software.

Puspitasari and Yancadianti, 2016. Analysis of the Selection of Environmentally Friendly Suppliers with the Analytical Network Process (ANP) Method at PT. Kimia Farma Plant Semarang. Undip Industrial Engineering Faculty, Semarang.

Saaty. T. L. 1991. Decision Making For Leaders, PT. Pustaka Binaman Pressindo Jakarta 1991.

Saaty, T. L. 2001. "Decision Making with Dependence and Feedback The Analytic Network Process (2nd ed.)". RWS Publication. Pittsburgh, USA.

Shiue, Y.C., and Lin, C.Y., 2012. Applying analytic network processes to evaluate the optimal recycling strategy in the upstream of the solar energy industry, Energy and Buildings.

Wibisono and Gondo, 2013. Supplier Selection Using Analytic Network Process (ANP) Method, Case Study in PT. Al. Faculty of Industrial Engineering Unpar Bandung. 